\title{
Influence of different annealing processes under various atmospheres on the oxidation behaviour of $\gamma$-TiAl
}

\author{
A. Ebach-Stahl ${ }^{a *}$, M. Fröhlich $^{\mathrm{a}}$ and C. Leyens ${ }^{\mathrm{a}, \mathrm{b}}$ \\ ${ }^{a}$ DLR-German Aerospace Center, Institute of Materials Research, 51170 Cologne, \\ Germany *E-mail: andrea.ebach@dir.de \\ ${ }^{b}$ Technical University of Brandenburg at Cottbus, Chair of Physical Metallurgy and \\ Materials Technology, 03046 Cottbus, Germany
}

\begin{abstract}
A detailed study of the oxidation behaviour of bare $\gamma$-TiAl based alloy $\mathrm{Ti}-45 \mathrm{Al}-8 \mathrm{Nb}$ under various conditions, such as different atmospheres, pressures, temperatures $\left(900^{\circ} \mathrm{C}, 1000^{\circ} \mathrm{C}\right)$ and times $(100-$ $200 \mathrm{~h})$ is presented. Under high vacuum conditions $\left(10^{-6} \mathrm{mbar}\right)$ a continuous zone of $\alpha_{2}-\mathrm{Ti}_{3} \mathrm{Al}$ was formed at the surface with an oxygen-enriched phase on top. No oxide scale formation was obvious. During thermal treatment under Ar-atmosphere at low vacuum pressure (approximately $50 \mathrm{mbar}$ ) mainly nitrides (TiN, $\mathrm{Ti}_{2} \mathrm{AlN}$ ) and $\mathrm{Al}_{2} \mathrm{O}_{3}$ particles were formed at the surface with an $\alpha_{2}$-layer below. Annealing $\gamma$-TiAl in hydrogen atmosphere (about 1040 mbar) led to the formation of a thick reaction zone. $\mathrm{A} \mathrm{TiO}_{2}$ layer was formed on top, followed by a mixed oxide scale. Beneath that scale a thick region with alumina, $\sigma-\mathrm{Nb}_{2} \mathrm{Al}$ and $\alpha_{2}-\mathrm{Ti}_{3} \mathrm{Al}$ was observed.

Moreover, the oxidation behaviour of several thermally pre-treated samples was tested by cyclic oxidation at $900^{\circ} \mathrm{C}$ in air. The microstructure of the oxide scale formed after testing can be compared with that of non pre-treated material. $\gamma$-TiAl annealed under high vacuum conditions exhibits the lowest oxidation rate, while the mass gain of specimens pre-treated under Ar-atmosphere increased rapidly in the first cycles. All pre-treated specimens exceeded a lifetime of 600 cycles at minimum. The reference material failed after 520 cycles.
\end{abstract}

Keywords: titanium aluminides, vacuum annealing, argon annealing, hydrogen annealing, oxidation behaviour

\section{INTRODUCTION}

Materials with a low density for high temperature applications are interesting in aerospace and automotive industries. Especially, $\gamma$-TiAl based alloys are attractive due to their good mechanical properties, such as low density, high stiffness, high yield strength and good creep resistance in a temperature range from $700^{\circ} \mathrm{C}$ up to $900^{\circ} \mathrm{C}[1-4]$. Titanium aluminides based on $\gamma$-TiAl were tested successfully as parts of automotive engines $[2,3]$ as well as components in aeroengines [4], such as low-pressure turbine blades. However, the oxidation rates of titanium aluminides typically increase greatly above temperatures of $750^{\circ} \mathrm{C}$ due to the formation of fast growing porous titania scales [5-9].

Different thermal treatments can improve the oxidation resistance of titanium aluminides as extensively discussed in the literature [10-14]. It is reported that annealing under various atmospheres and partial pressures of oxygen, nitrogen and hydrogen leads to the formation of different phases as well as the growth of various oxide scales on $\gamma$ TiAl, finally affecting the oxidation resistance of the material.
In this study $\gamma$-TiAl was thermally pre-treated in high vacuum, Ar-atmosphere as well as hydrogen under various pressures and then tested in air to compare the oxidation behaviour to non pre-treated material.

\section{E3XPERIMENTAL}

\subsection{Annealing series of $\gamma$-TiAl}

The oxidation experiments were performed on $\gamma$-TiAl based alloy $\mathrm{Ti}-45 \mathrm{Al}-8 \mathrm{Nb}$ (in at.\%), provided by GKSS (Research Center Geesthacht). The specimens were ground by $\mathrm{SiC}$ paper up to 4000 grit, polished and ultrasonically cleaned in ethanol before testing.

In a special high-temperature furnace the annealing experiments were performed under three various atmospheres (high vacuum, Ar-atmosphere and $\mathrm{H} 2$-atmosphere) at two different temperatures $\left(900^{\circ} \mathrm{C}\right.$ and $\left.1000^{\circ} \mathrm{C}\right)$, shown in Table 1 .

Before starting each pre-treatment process of the furnace was evacuated to $10^{-6} \mathrm{mbar}$. During high vacuum annealing the specimens were heated to set point temperature, held for the according time and subsequently cooled down. In the 
Table 1 Pre-treatment annealing conditions

\begin{tabular}{lccc}
\hline & High vacuum & Ar-atmosphere & $\mathrm{H}_{2}$-atmosphere \\
\hline $900^{\circ} \mathrm{C}$ & $100 \mathrm{~h}$ & $100 \mathrm{~h}$ & - \\
$1000^{\circ} \mathrm{C}$ & $100 \mathrm{~h}, 200 \mathrm{~h}$ & $100 \mathrm{~h}, 200 \mathrm{~h}$ & $10 \mathrm{~h}$ \\
\hline
\end{tabular}

second pre-treatment process, the chamber was flooded by $\operatorname{Ar}$ (purity: 99,996\%) up to a pressure of $10 \mathrm{mbar}$ before heating. At exposure temperature a pressure of $50 \mathrm{mbar}$ was reached. At annealing in hydrogen atmosphere (purity: 99,993\%) it was necessary to work with an absolute pressure of 1040 mbar. The furnace chamber was filled with hydrogen until the pressure was reached by operating at a gas flow of $5 \mathrm{~L} / \mathrm{h}$. The heating rate for all thermal treatments was $4 \mathrm{~K} / \mathrm{min}$.

Post-oxidation investigations of the microstructure were performed using a LEO Gemini field emission gun scanning electron microscope (SEM) equipped with an Oxford energy-dispersive X-ray spectrometry (EDS) detector attached. Chemical compositions were determined using semi-quantitative analysis for spot and line scan measurements.

\subsection{Cyclic oxidation test of annealed $\gamma$-TiAl}

After pre-treatment the material was tested under cyclic conditions in air at $900^{\circ} \mathrm{C}$. One cycle consisted of $1 \mathrm{~h}$ heating and $10 \mathrm{~min}$ cooling down to $60^{\circ} \mathrm{C}$. During cyclic testing the mass gain was measured at certain intervals. Oxide scale spallation was considered as sample failure. For comparison a non pre-treated $\gamma$-TiAl specimen was tested. After testing the specimens were investigated by means of SEM and EDS analysis.

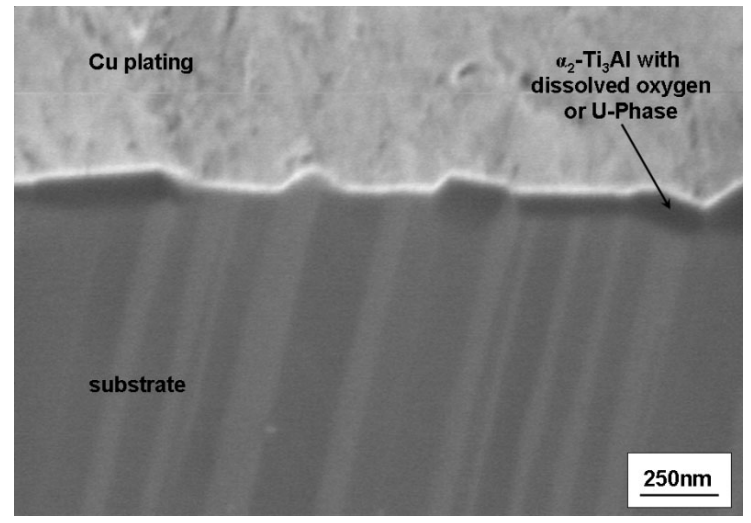

Figure 1 SEM micrograph of TiAl samples after high-vacuum annealing at $900^{\circ} \mathrm{C}$ for $100 \mathrm{~h}$.

\section{RESULTS AND DISCUSSION}

\subsection{Annealing pre-treatment of $\gamma$-TiAl}

The oxidation behaviour of $\gamma$-TiAl varies under different oxygen and nitrogen partial pressures [15-20]. In Table 2 the values of partial pressures used in the experiments are listed. Since the oxygen partial pressures were much higher than the decomposition pressure of the oxides [21], oxidation processes were expected during each pre-treatment.

\section{High vacuum annealing}

During high-vacuum annealing at $900^{\circ} \mathrm{C}$ for $100 \mathrm{~h}$ phase changes took place at the surface (Figure 1). On top of the $\gamma$ TiAl based alloy consisting of $\gamma$-TiAl- and $\alpha_{2}-\mathrm{Ti}_{3} \mathrm{Al}$ lamellae $[3,22]$, a thin (few hundreds of nanometers) subsurface zone

Table 2 Oxygen, nitrogen and water partial pressures during different heat treatments (a) high vacuum annealing, (b) argon annealing, and (c) hydrogen annealing

(a)

\begin{tabular}{lccc}
\hline Elements in atmosphere & $\begin{array}{c}\text { Ratio } \mathrm{n}_{\mathrm{i}} \\
{[\%]}\end{array}$ & $\begin{array}{c}\text { Experimental pressure } \mathrm{p} \\
{[\mathrm{mbar}]}\end{array}$ & $\begin{array}{c}\text { Partial pressure } \mathrm{p}_{\mathrm{i}} \\
{[\mathrm{mbar}]}\end{array}$ \\
\hline Oxygen $\left(\mathrm{O}_{2}\right)$ & 21 & $1.00 \mathrm{E}-06$ & $2.10 \mathrm{E}-07$ \\
Nitrogen $\left(\mathrm{N}_{2}\right)$ & 78 & $1.00 \mathrm{E}-06$ & $2.80 \mathrm{E}-07$ \\
\hline
\end{tabular}

(b)

\begin{tabular}{lccc}
\hline Elements in argon 4.6 & $\begin{array}{c}\text { Ratio } \mathrm{n}_{\mathrm{i}} \\
{[\mathrm{ppm}]^{\mathrm{a}}}\end{array}$ & $\begin{array}{c}\text { Experimental pressure } \mathrm{p} \\
{[\mathrm{mbar}]}\end{array}$ & $\begin{array}{c}\text { Partial pressure } \mathrm{p}_{\mathrm{i}} \\
{[\mathrm{mbar}]}\end{array}$ \\
\hline Oxygen $\left(\mathrm{O}_{2}\right)$ & 6 & 50 & $3.00 \mathrm{E}-04$ \\
Nitrogen $\left(\mathrm{N}_{2}\right)$ & 20 & 50 & $1.00 \mathrm{E}-03$ \\
\hline
\end{tabular}

(c)

\begin{tabular}{lccc}
\hline Elements in hydrogen 4.3 & $\begin{array}{c}\text { Ratio } \mathrm{n}_{\mathrm{i}} \\
{[\mathrm{ppm}]^{\mathrm{a}}}\end{array}$ & $\begin{array}{c}\text { Experimental pressure } \mathrm{p} \\
{[\mathrm{mbar}]}\end{array}$ & $\begin{array}{c}\text { Partial pressure } \mathrm{p}_{\mathrm{i}} \\
\text { [mbar] }\end{array}$ \\
\hline Oxygen $\left(\mathrm{O}_{2}\right)$ & 2 & 1040 & $2.08 \mathrm{E}-03$ \\
Nitrogen $\left(\mathrm{N}_{2}\right)$ & 50 & 1040 & $5.20 \mathrm{E}-02$ \\
Water $\left(\mathrm{H}_{2} \mathrm{O}\right)$ & 20 & 1040 & $2.08 \mathrm{E}-02$ \\
\hline
\end{tabular}

$\mathrm{n}_{\mathrm{i}}$-content of the element/molecule.

${ }^{\mathrm{a}}$ According to gas supplier specifications. 
(a)

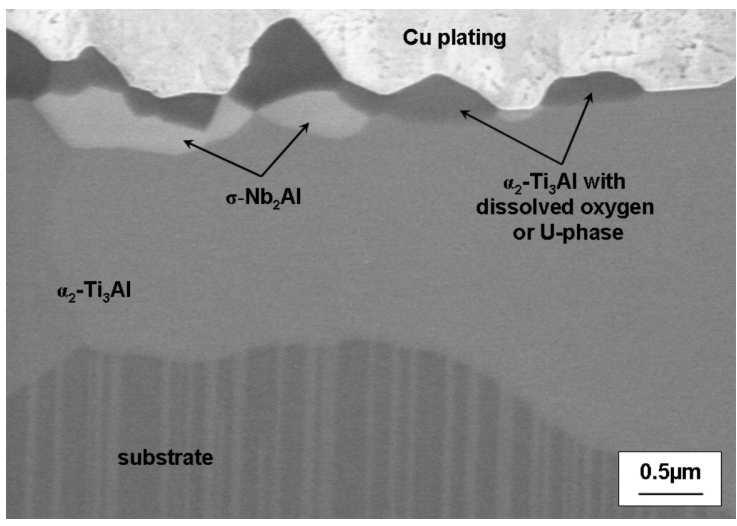

(b)

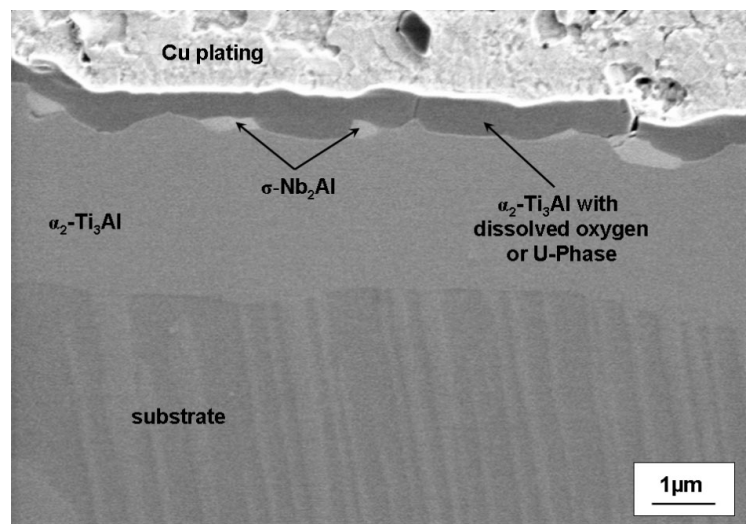

Figure 2 Cross-section of TiAl samples after high-vacuum annealing at $1000^{\circ} \mathrm{C}$ for (a) $100 \mathrm{~h}$; (b) $200 \mathrm{~h}$.

formed. Due to the marginal dimensions the nature of this zone could not be identified by EDS analysis.

At $1000^{\circ} \mathrm{C}$ the subsurface zone thickened substantially, forming a continuous layer after $200 \mathrm{~h}$ (Figure 2). According to the measured composition (Table 3 ) this zone could be concluded to contain $\alpha_{2}-\mathrm{Ti}_{3} \mathrm{Al}$ phase with 15 at.\% oxygen in solution. Earlier studies by Dettenwanger and Schütze on the oxidation behaviour of $\alpha_{2}-\mathrm{Ti}_{3} \mathrm{Al}$ showed the formation of a Ti-21Al-15O (at.\%) layer [23] with an unknown crystallographic structure. The composition of the phase observed at the surface of the vacuum pre-treated specimens (Ti$4.6 \mathrm{Nb}-23.2 \mathrm{Al}-15 \mathrm{O})$ is close to that phase found by the above mentioned authors. According to Dettenwanger and Schütze the nature of this phase is still unknown; therefore, the phase will be denoted as "U-phase" in the following. Below the U-phase precipitations of a Nb-rich phase, presumably $\sigma-\mathrm{Nb}_{2} \mathrm{Al}$ phase [24-27], and a thick $\alpha_{2}-\mathrm{Ti}_{3} \mathrm{Al}$ zone were formed at $1000^{\circ} \mathrm{C}$ after $100 \mathrm{~h}$ (Figure 2a). Within the latter phase no oxygen could be measured (Table 3 ). Upon extended exposure, the U-phase formed a continuous layer on top of the $\alpha_{2}-\mathrm{Ti}_{3} \mathrm{Al}$ phase (Figure 2b). Due to the high niobium content of 10.5 at. $\%$ in the $\alpha_{2}-\mathrm{Ti}_{3} \mathrm{Al}$ phase region compared to its concentration in the outer phase (4.6 at.\%) it could be assumed that formation of the U- phase led to enrichment of $\mathrm{Nb}$ at the interface between $\mathrm{U}$ phase and $\alpha_{2}$-phase resulting in the growth of $\sigma-\mathrm{Nb}_{2} \mathrm{Al}$.

The reason for the formation of continuous $\alpha_{2}-\mathrm{Ti}_{3} \mathrm{Al}$ zone at the surface is not clear yet. It could be induced by the presence of oxygen, in this case probably by attendance of the U-phase. Another reason could be that $\alpha_{2}-\mathrm{Ti}_{3} \mathrm{Al}$ is more thermodynamically stable. Kattner et al. determined the temperature-dependent Gibbs-energy $\Delta G^{f}$ of the $\alpha_{2}-\mathrm{Ti}_{3} \mathrm{Al}$ and $\gamma$-TiAl [28]:

$$
\begin{gathered}
\Delta G_{\alpha_{2}}^{f}=(-29,633.6+6.70801 \cdot T) \frac{J}{\text { mol atom }} \\
\Delta G_{\gamma}^{f}=(-37,445.1+16.79376 \cdot T) \frac{J}{\mathrm{~mol} \text { atom }}
\end{gathered}
$$

These equations indicate that the Gibbs-energy of the $\alpha_{2}$ phase is lower than that of the $\gamma$-phase above approximately $775 \mathrm{~K}$. That means, the $\alpha_{2}$-phase is more thermodynamically stable especially at the surface, where no local equilibrium between both phases exists.

Unexpectedly, neither oxides nor nitrides were formed under the high vacuum conditions at 900 and/or $1000^{\circ} \mathrm{C}$.

\begin{tabular}{|c|c|c|c|c|c|c|}
\hline \multirow[t]{2}{*}{ System } & \multirow[t]{2}{*}{ Phases } & \multicolumn{5}{|c|}{ Composition c [at.\%] } \\
\hline & & $\mathrm{N}$ & $\mathrm{O}$ & $\mathrm{Al}$ & $\mathrm{Ti}$ & $\mathrm{Nb}$ \\
\hline $\begin{array}{l}\text { High vacuum annealing } \\
\text { (Figure } 2 \text { ) }\end{array}$ & $\begin{array}{l}\alpha_{2}-\mathrm{Ti}_{3} \mathrm{Al}+\mathrm{O} \\
\text { or U-phase } \\
\text { presumably } \sigma-\mathrm{Nb}_{2} \mathrm{Al} \\
\alpha_{2}-\mathrm{Ti}_{3} \mathrm{Al}\end{array}$ & $\begin{array}{l}- \\
- \\
-\end{array}$ & $\begin{array}{c}15.0 \\
- \\
-\end{array}$ & $\begin{array}{l}23.2 \\
31.8 \\
33.6\end{array}$ & $\begin{array}{l}57.2 \\
51.4 \\
55.9\end{array}$ & $\begin{array}{r}4.6 \\
16.8 \\
10.5\end{array}$ \\
\hline $\begin{array}{l}\text { Annealing under Ar- } \\
\text { atmosphere } \\
\text { (Figure 3) }\end{array}$ & $\begin{array}{l}\mathrm{TiN} \\
\mathrm{Ti}_{2} \mathrm{AlN} \\
\mathrm{Al}_{2} \mathrm{O}_{3} \\
\alpha_{2}-\mathrm{Ti}_{3} \mathrm{Al} \\
\sigma-\mathrm{Nb}_{2} \mathrm{Al}\end{array}$ & $\begin{array}{l}45.0 \\
35.2 \\
- \\
- \\
-\end{array}$ & $\begin{array}{l}- \\
- \\
63.8 \\
- \\
-\end{array}$ & $\begin{array}{r}0.7 \\
7.8 \\
34.4 \\
31.2 \\
34.7\end{array}$ & $\begin{array}{r}53.4 \\
56.3 \\
1.7 \\
64.6 \\
28.8\end{array}$ & $\begin{array}{r}0.9 \\
0.7 \\
0.2 \\
4.2 \\
36.5\end{array}$ \\
\hline $\begin{array}{l}\text { Annealing under } \\
\mathrm{H}_{2} \text {-atmosphere } \\
\text { (Figure 4) }\end{array}$ & $\begin{array}{l}\mathrm{TiO}_{2} \\
\text { mixed oxides } \\
\mathrm{Al}_{2} \mathrm{O}_{3} \\
\sigma-\mathrm{Nb}_{2} \mathrm{Al} \\
\alpha_{2}-\mathrm{Ti}_{3} \mathrm{Al}\end{array}$ & $\begin{array}{l}- \\
- \\
- \\
- \\
-\end{array}$ & $\begin{array}{c}67.5 \\
65-75 \\
61.8 \\
- \\
-\end{array}$ & $\begin{array}{c}- \\
10-20 \\
27.1 \\
29.6 \\
30.2\end{array}$ & $\begin{array}{c}32.5 \\
7-15 \\
9.3 \\
41.0 \\
57.9\end{array}$ & $\begin{array}{r}- \\
1-6 \\
1.8 \\
29.4 \\
11.9\end{array}$ \\
\hline
\end{tabular}

Table 3 Composition of phases of differently pre-treated TiAl-material measured by EDX; concentration in at.\% 
(a)

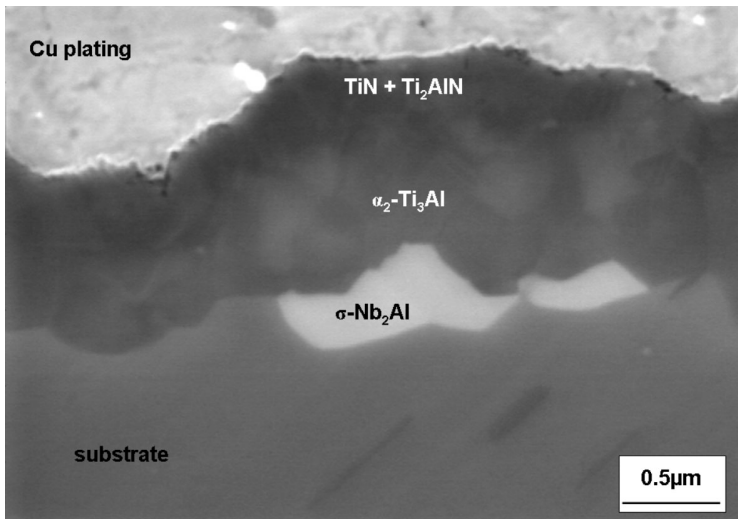

(b)

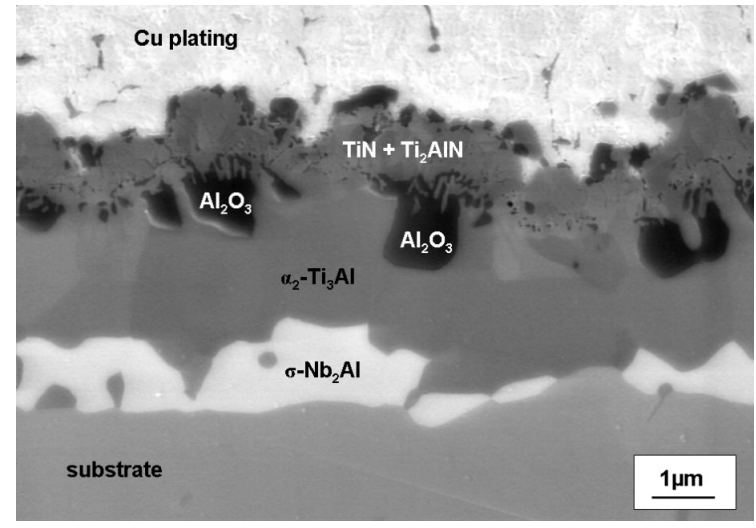

Figure 3 Cross-section of TiAl samples after annealing under Ar-atmosphere for $100 \mathrm{~h}\left(\right.$ a) at $900^{\circ} \mathrm{C}$; (b) at $1000^{\circ} \mathrm{C}$.

\section{Annealing under Ar-atmosphere}

During the annealing processes under Ar-atmosphere the partial pressures of oxygen and nitrogen were much higher compared to the vacuum pre-treatment (Table 2).

As shown in Figure 3 mainly nitrides $\mathrm{TiN}$ and $\mathrm{Ti}_{2} \mathrm{AlN}$ were formed at the surface as founded in the transition region during usual oxidation processes of $\gamma$-TiAl in air $[29,30]$. The nitrides were seen at both annealing temperatures $\left(900^{\circ} \mathrm{C}\right.$ and $\left.1000^{\circ} \mathrm{C}\right)$. Below this nitride layer different intermetallic phases were formed. $\alpha_{2}-\mathrm{Ti}_{3} \mathrm{Al}$ grew continuously beneath the nitrides. Niobium enriched precipitates, presumably $\sigma-\mathrm{Nb}_{2} \mathrm{Al}$, were formed at the $\alpha_{2}-\mathrm{Ti}_{3} \mathrm{Al} / \gamma-\mathrm{TiAl}$ interface. It can be assumed that the formation of this phase is caused by titanium consumption as a result of $\alpha_{2}-\mathrm{Ti}_{3} \mathrm{Al}$ growth. The composition of phases is shown in Table 3 .

In spite of the relatively high oxygen partial pressure $\left(3 \times 10^{-4}\right.$ mbar $)$ no oxidation took place at $900^{\circ} \mathrm{C}$. However, the nitrogen partial pressure $\left(10^{-3}\right.$ mbar $)$ was obviously sufficient to form a continuous nitride layer at the surface.

After $100 \mathrm{~h}$ at $1000^{\circ} \mathrm{C}$ additionally precipitates of alumina were formed at the nitride $/ \alpha_{2}-\mathrm{Ti}_{3} \mathrm{Al}$ interface. According to the results of the high vacuum annealing experiments, presumably the $\alpha_{2}$-phase should be formed first. Subsequently the growth of the nitrides and alumina could take place simultaneously. The oxygen partial pressure was too low for the formation of titania [21].

With longer exposure times up to $200 \mathrm{~h}$ at $1000^{\circ} \mathrm{C}$ all phases grew substantially. The thickness of the reaction zone increases from 4.5 up to $7.5 \mu \mathrm{m}$. The $\sigma-\mathrm{Nb}_{2} \mathrm{Al}$ formed a nearly continuous layer below the $\alpha_{2}-\mathrm{Ti}_{3} \mathrm{Al}$ phase.

\section{Annealing under $\mathrm{H}_{2}$-atmosphere}

SEM analysis shows the formation of a reaction zone, approximately $20 \mu \mathrm{m}$ in thickness, after $10 \mathrm{~h}$ at $1000^{\circ} \mathrm{C}$ under hydrogen atmosphere at 1040 mbar (Figure 4). A mixed oxide scale mainly consisting of titania and alumina was formed, accompanied by a dense titania layer on top (Table 3). Beneath that scale a huge mixed zone consisting of alumina, $\alpha_{2}-\mathrm{Ti}_{3} \mathrm{Al}$ and $\sigma-\mathrm{Nb}_{2} \mathrm{Al}$ precipitates could be observed.
The oxygen and nitrogen partial pressures were much higher in hydrogen than in the other atmospheres (Table 2). However, in the $\mathrm{H}_{2}$-atmosphere the oxygen partial pressure could be reduced by the formation of $\mathrm{H}_{2} \mathrm{O}$ :

$$
2 \mathrm{H}_{2}+\mathrm{O}_{2} \Longleftrightarrow 2 \mathrm{H}_{2} \mathrm{O}
$$

Therefore the oxide formation should be suppressed. However, investigations of Kremer and Auer revealed poor oxidation behaviour of $\gamma$-TiAl in water vapour containing atmosphere caused by enhanced $\mathrm{Al}_{2} \mathrm{O}_{3}$ growth [20]. These results are in good agreement with the present findings on enhanced oxidation in hydrogen containing atmosphere. The massive growth of alumina can be explained concerning the following reaction [19]:

$$
2 \mathrm{Al}+\mathrm{TiO}_{2}+\mathrm{H}_{2} \mathrm{O} \Longleftrightarrow \mathrm{H}_{2}+\mathrm{Ti}+\mathrm{Al}_{2} \mathrm{O}_{3}
$$

According to Zeller et al. water molecules are dissociated on rutile by forming $\mathrm{H}$ and $\mathrm{OH}^{-}$[31]. The dissolution of $\mathrm{H}$ atoms or $\mathrm{OH}^{-}$groups could lead to a change in the defect chemistry of $\mathrm{TiO}_{2}$ and therefore in the transport mechanisms through titania, finally resulting in enhanced oxidation of $\gamma$ TiAl.

The primary inward growth of $\mathrm{Al}_{2} \mathrm{O}_{3}$ induced the depletion of aluminum in the $\gamma$-TiAl phase leading to the formation of $\alpha_{2}-\mathrm{Ti}_{3} \mathrm{Al}$ and $\sigma-\mathrm{Nb}_{2} \mathrm{Al}$. Nitrides could not be observed.

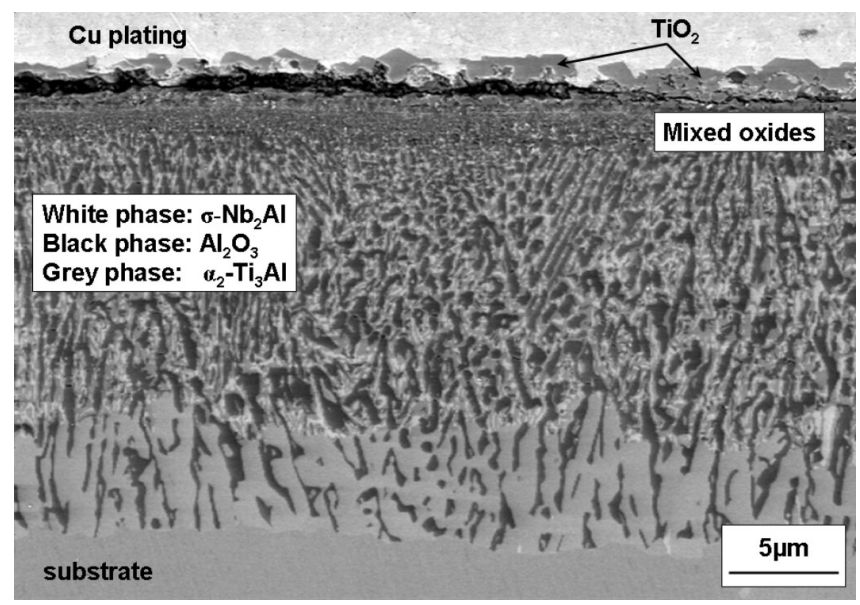

Figure 4 SEM micrograph of TiAl samples after annealing under $\mathrm{H}_{2}$-atmosphere at $1000^{\circ} \mathrm{C}$ for $10 \mathrm{~h}$. 


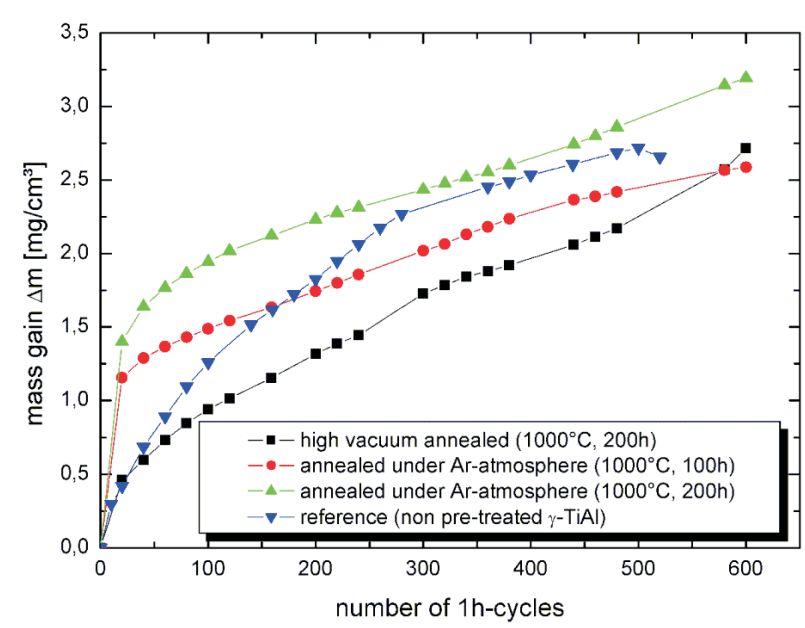

Figure 5 Oxidation kinetics of pre-treated and non pre-treated $\gamma$-TiAl thermally cycled at $900^{\circ} \mathrm{C}$ in air.

Due to the enhanced oxide formation, exposure under hydrogen atmosphere is not appropriate to increase the oxidation resistance of $\gamma$-TiAl. Therefore, hydrogen pretreatments were not considered further for sample exposure to air.

\subsection{Cyclic oxidation test of pre-treated $\gamma$-TiAl}

The oxidation behaviour of the differently pre-treated $\gamma$-TiAl alloy was compared with that of non pre-treated samples by

(a)

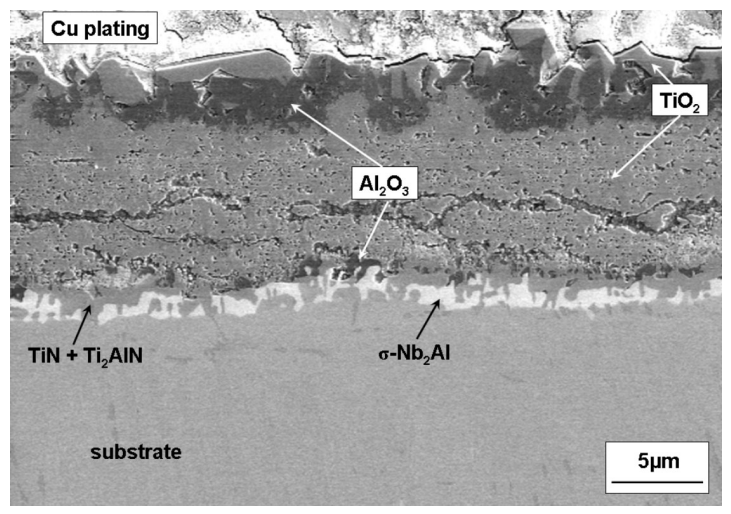

(c)

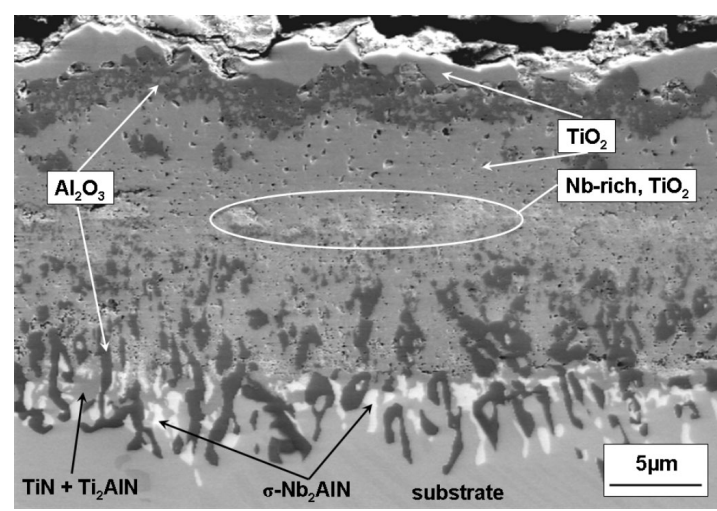

cyclic testing in air at $900^{\circ} \mathrm{C}$. The measurements show that the high vacuum annealed specimen has the lowest oxidation rate, followed by non pre-treated material with a slightly higher mass gain (Figure 5). The material pre-treated in Aratmosphere exhibited the highest mass gain, especially within the first 20 cycles. Therefore the nitrides on top of the samples grown during the annealing process under Ar, seem to oxidize much faster than the intermetallic $\alpha_{2}$ - and $\gamma-$ phases at $900^{\circ} \mathrm{C}$. This effect is also described by Rakowski et al. and Zheng et al. [18,32]. But after the high mass gain in the first cycles the oxidation kinetics of $\gamma$-TiAl annealed under Ar-atmosphere reveal a lower slope compared to the sample pre-treated under high vacuum conditions as well as to the reference material.

The non pre-treated material failed after 520 cycles while the other specimens showed no spallation up to 600 cycles when the test was terminated for microstructures investigations of the oxide scale.

Although on top of the high vacuum annealed specimen Ti-rich $\alpha_{2}$-phase was present before cyclic testing, the material showed the lowest mass gain accompanied with the thinnest oxide scale of all samples tested (Figure 6). Compared to the reference material a higher oxidation rate was expected due to the high Ti-content as described by Dettenwanger and Schütze [23]. Presumably the presence of a continuous layer of the oxygen-containing U-phase on the surface affected the oxidation behaviour beneficially. This effect is not yet fully clear and will be investigated in more detail in further experiments.

(b)

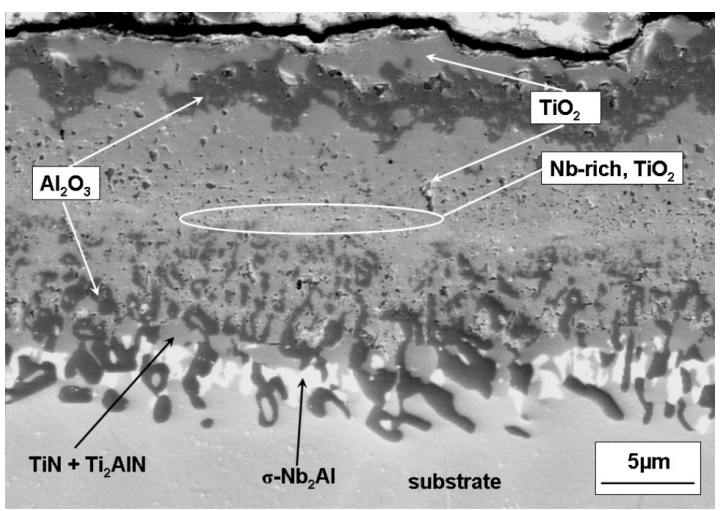

(d)

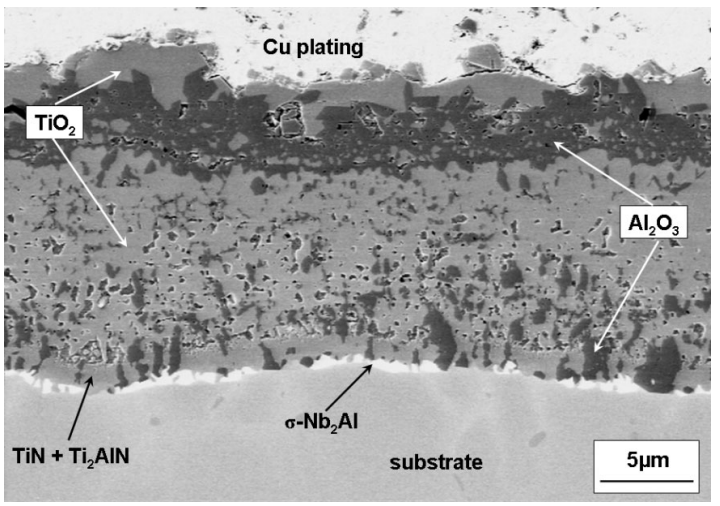

Figure 6 Cross-section of variously pre-treated specimens, cyclic tested at $900^{\circ} \mathrm{C}$ in air for (a) 600 cycles; high vacuum annealing at $1000^{\circ} \mathrm{C}$ for $200 \mathrm{~h}$; (b) 600 cycles; annealing under Ar-atmosphere at $1000^{\circ} \mathrm{C}$ for $100 \mathrm{~h}$; (c) 600 cycles; annealing under Ar-atmosphere at $1000^{\circ} \mathrm{C}$ for $200 \mathrm{~h}$; (d) 520 cycles; non pre-treated $\gamma$-TiAl. 


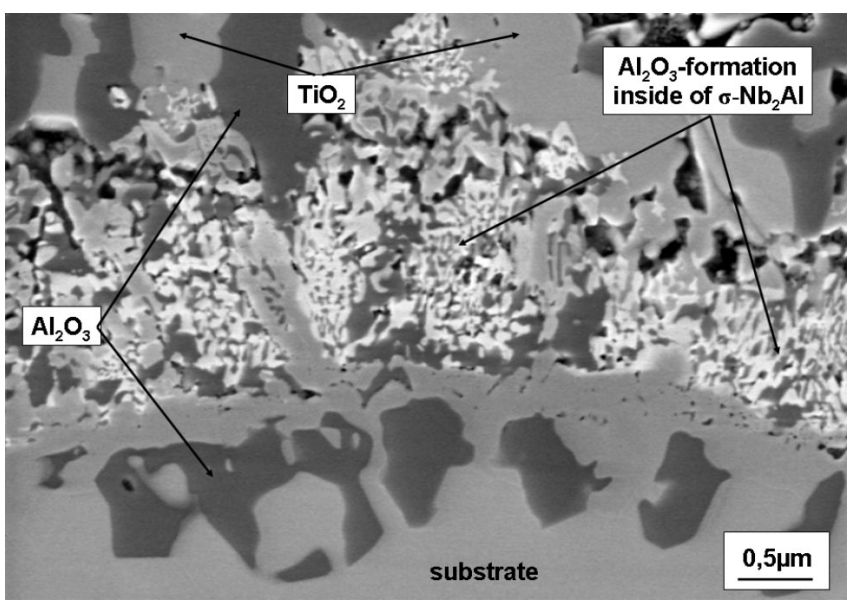

Figure $7 \mathrm{SEM}$ micrograph of $\sigma-\mathrm{Nb}_{2} \mathrm{Al}$ with an enhanced alumina formation.

The scale microstructure of the Ar annealed specimens differs slightly. In the bottom part of the oxide scale the concentration of $\mathrm{Al}_{2} \mathrm{O}_{3}$ particles is higher compared to the reference sample. Furthermore, a zone of $\mathrm{Nb}$-enriched $\mathrm{TiO}_{2}$ (composition: $(64-74) \mathrm{O}-(4-12) \mathrm{Al}-(10-14) \mathrm{Ti}-(7-15) \mathrm{Nb})$ was present directly above the region with alumina precipitates (Figure 6b,c). Due to the formation of a distinct $\sigma-\mathrm{Nb}_{2} \mathrm{Al}$ zone after pre-treatment in argon it can be assumed that an enhanced alumina formation occurred in air according to oxidation of the $\sigma$-phase (composition: $(37-47) \mathrm{O}-(15-18) \mathrm{Al}-(11-16) \mathrm{Ti}-(22-30) \mathrm{Nb})$, shown in Figure 7. In addition to the $\mathrm{Al}_{2} \mathrm{O}_{3}$ growth, $\mathrm{Nb}$ enriched in the growing $\mathrm{TiO}_{2}$ scale during oxidation of $\mathrm{Nb}_{2} \mathrm{Al}$. The distinct alumina region at the scale bottom could have led to the noticeably lower mass gain after approximately 20 1 h-cycles (Figure 5).

\section{CONCLUSIONS}

High-temperature annealing experiments under various atmospheres exhibit no oxidation processes under high vacuum conditions $\left(\mathrm{p}=10^{-6} \mathrm{mbar}\right)$ at $1000^{\circ} \mathrm{C}$. Mainly $\alpha_{2}-$ $\mathrm{Ti}_{3} \mathrm{Al}$-phase was formed underneath the surface. In the outer part, a zone was formed in which 15 at.\% oxygen was measured; either oxygen was dissolved in $\alpha_{2}-\mathrm{Ti}_{3} \mathrm{Al}$ or formed a new phase (unknown "U-phase").

Under Ar-atmosphere at $900^{\circ} \mathrm{C}$ nitrides $\left(\mathrm{TiN}+\mathrm{Ti}_{2} \mathrm{AlN}\right)$ were formed at the surface. Below this layer a zone of $\alpha_{2}$ $\mathrm{Ti}_{3} \mathrm{Al}$ was observed. At an annealing temperature of $1000^{\circ} \mathrm{C}$ precipitations of alumina formed additionally at the nitride $/ \alpha_{2}-\mathrm{Ti}_{3} \mathrm{Al}$ interface.

Much stronger oxidation occurred during exposure in hydrogen. A $20 \mu \mathrm{m}$ thick oxide scale was formed already after $10 \mathrm{~h}$, mainly consisting of a mixture of alumina, $\alpha_{2}-$ $\mathrm{Ti}_{3} \mathrm{Al}$ and $\sigma-\mathrm{Nb}_{2} \mathrm{Al}$. At the surface a mixed oxide scale was grown with a dense $\mathrm{TiO}_{2}$ layer on top.

Oxidation tests in air at $900^{\circ} \mathrm{C}$ exhibited different results of the differently pre-treated samples. The high vacuum annealed material showed the lowest oxidation rate presumably caused by the presence of the U-phase. The mass gain of the Ar-atmosphere pre-treated material increased much faster in the first test cycles because of the high amount of nitrogen contained in the nitride layer leading to enhanced formation of titania. Upon extended exposure the mass gain increased rapidly, presumably due to the formation of $\mathrm{Al}_{2} \mathrm{O}_{3}$ caused by oxidation of $\sigma-\mathrm{Nb}_{2} \mathrm{Al}$ in the transition region. Although no continuous alumina scale was formed at the surface all pre-treated samples obtained a longer lifetime at $900^{\circ} \mathrm{C}$ than the reference material.

\section{REFERENCES}

[1] Clemens, H. and Kestler, H. (2000) Processing and applications of intermetallic $\gamma$-TiAl-based alloys. Adv. Engng. Mater., 2(9), 551-570.

[2] Clemens, H., Appel, F., Bartels, A., Baur, H., Gerling, R., Güther, V. and Kestler, K. (2004) Processing and application of engineering $\gamma$-TiAl based alloys. In: Lütjering, G. and Albrecht, J. (eds.), Ti-2003, Science and technology, Vol. 4, pp. 2123-2136. Wiley-VCH Verlag, Weinheim.

[3] Kestler, H. and Clemens, H. (2002) Production, processing and application of $\gamma(\mathrm{TiAl})$-based alloys. In: Peters, M. and Leyens, C. (eds.), Titanium and titanium alloys, pp. 351-392. Wiley-VCH Verlag, Weinheim.

[4] Baur, H. and Wortberg, D.B. (2004) Titanium aluminides for automotive applications. In: Lütjering, G. and Albrecht, J. (eds.), Ti-2003, Science and technology, Vol. 5, pp. 34113418. Wiley-VCH Verlag, Weinheim.

[5] Smarsly, W., Baur, H., Glitz, G., Clemens, H., Khan, T. and Thomas, M. (2001) Titanium aluminides for automotive and gas turbine applications. In: Hemker, K. J. et al. (eds.), Structural intermetallics, pp. 25-34. TMS-The Minerals, Metals \& Materials Society.

[6] Brady, M.P., Brindley, W.J., Smialek, J.L. and Locci, I.E. (1996) The oxidation and protection of gamma titanium aluminides. JOM, 48, 46-50.

[7] Okafor, I.C.I. and Reddy, R.G. (1999) The oxidation behavior of high-temperature aluminides. JOM, 51, 35-39.

[8] Yoshihara, M. and Kim, Y.-W. (2005) Oxidation behaviour of gamma alloys designed for high temperature applications. Intermetallics, 13, 952-958.

[9] Schmitz-Niederau, M. and Schütze, M. (1999) The oxidation behavior of several Ti-Al alloys at $900^{\circ} \mathrm{C}$ in air. Oxidat. Met., 52(3/4), 225-240.

[10] Becker, S., Rahmel, A., Schorr, M. and Schütze, M. (1992) Mechanism of isothermal oxidation of the intermetallic TiAl and of TiAl alloys. Oxidat. Met., 38(5/6), 425-464.

[11] Groß, M., Kolarik, V. and Rahmel, A. (1997) Scale formation on $\gamma$-TiAl during oxidation at 800 and $900^{\circ} \mathrm{C}$ in air and in $\mathrm{He}+20 \% \mathrm{O}_{2}$. Oxidat. Met., 48(1/2), 271-285.

[12] Rakowski, J.M., Meier, G.H., Pettit, F.S., Dettenwanger, F., Schumann, E. and Rühle, M. (1996) The effect of surface preparation on the oxidation behaviour of gamma TiAl-base intermetallic alloys. Scri. Mater., 35(12), 1417-1422.

[13] Shemet, V., Hoven, H. and Quadakkers, W.J. (1997) Oxygen uptake and depletion layer formation during oxidation of $\gamma$ TiAl based alloys. Intermetallics, 5, 311-320.

[14] Nickel, H., Zheng, N., Elschner, A. and Quadakkers, W.J. (1995) The oxidation behaviour of niobium containing $\gamma$-TiAl based intermetallics in air and argon/oxygen. Mikrochim. Acta, 119, S. 23-39.

[15] Taniguchi, S., Tachikawa, Y. and Shibata, T. (1997) Influence of oxygen partial pressure on the oxidation behaviour of TiAl at 1300 K. Mater. Sci. Engng., A232, 47-54. 
[16] Kovács, K., Perczel, I.V., Josepovits, V.K., Kiss, G., Réti, F. and Deák, P. (2002) In situ surface analytical investigation of the thermal oxidation of Ti-Al intermetallics up to $1000^{\circ} \mathrm{C}$. Appl. Surf. Sci., 200, 185-195.

[17] Quadakkers, W.J., Schaaf, P., Zheng, N., Gil, A. and Wallura, E. (1997) Beneficial and detrimental effects of nitrogen on the oxidation behaviour of TiAl-based intermetallics. Mater. Corros., 48, 28-34.

[18] Zheng, N., Quadakkers, W.J., Gil, A. and Nickel, H. (1995) Studies concerning the effect of nitrogen on the oxidation behavior of TiAl-based intermetallics at $900^{\circ} \mathrm{C}$. Oxidat. Met., 44(5/6), 477-499.

[19] Legzdina, D., Robertson, I.M. and Birnbaum, H.K. (2005) Oxidation behavior of a single $\gamma$-TiAl alloy in low-pressure oxygen and hydrogen. Acta Mater., 53, 601-608.

[20] Kremer, R. and Auer, W. (1997) Influence of moisture on the oxidation of $\gamma$-TiAl. Mater. Corros., 48, 35-39.

[21] Leyens, C. (2002) Oxidation and protection of titanium alloys and titanium aluminides. In: Peters, M. and Leyens, C. (eds.), Titanium and titanium alloys, pp. 187-230. Wiley-VCH, Weinheim.

[22] Appel, F. and Oehring, M. (2002) Titanium aluminide alloys: alloy design and properties. In: Peters, M. and Leyens, C. (eds.), Titanium and titanium alloys, pp. 89-152. Wiley-VCH, Weinheim.

[23] Dettenwanger, F. and Schütze, M. (2000) Isothermal oxidation of $\alpha_{2}-\mathrm{Ti}_{3} \mathrm{Al}$. Oxidat. Met., 54(1/2), 121-138.
[24] Brady, M.P., Verink, E.D. Jr. and Smith, J.W. (1999) Oxidation behavior of two-phase $\gamma+\sigma$ Nb-Ti-Al Alloys. Oxidat. Met., 51(5/6), 539-556.

[25] Chen, G.L., Wang, X.T., Ni, K.Q., Hao, S.M., Cao, J.X., Ding, J.J. and Zhang, X. (1996) Investigation on the 1000, 1150 and $1400^{\circ} \mathrm{C}$ isothermal section of the Ti-Al-Nb system. Intermetallics, 4, 13-22.

[26] Guilherme de Aragao, G.J. and Ebrahimi, F. (1996) High temperature deformation of Nb-Ti-Al alloys with $\sigma+\gamma$ microstructure. Mater. Sci. Engng., A208, 37-46.

[27] Dymek, S., Lorent, A., Wróbel, M. and Dollar, A. (2001) Mechanical alloying and microstructure of a $\mathrm{Nb}-20 \% \mathrm{~V}-$ 15\% Al alloy. Mater. Charact., 47, 375-381.

[28] Kattner, U.R., Lin, J.-C. and Chang, Y.A. (1992) Thermodynamic assessment and calculation of the Ti-Al system. Metall. Trans., 23A, 2081-2090.

[29] Zhao, B., Wu, J., Sun, J., Tu, B. and Wang, F. (2001) Effect of nitridation on the oxidation behaviour of TiAl-based intermetallic alloys. Intermetallics, 9, 697-703.

[30] Dettenwanger, F., Schumann, E., Rühle, M., Rakowski, J. and Meier, G.H. (1998) Microstructural study of oxidized $\gamma$-TiAl. Oxidat. Met., 50(3/4), 269-307.

[31] Zeller, A., Dettenwanger, F. and Schütze, M. (2002) Influence of water vapour on the oxidation behaviour of titanium aluminides. Intermetallics, 10, 59-72.

[32] Rakowski, J.M., Pettit, F.S., Meier, G.H., Dettenwanger, F., Schumann, E. and Rühle, M. (1995) The effect of nitrogen on the oxidation of $\gamma$-TiAl. Scri. Metal. Mater., 33, 997-1003. 